\title{
廃棄物処分場における遮水工としての膨潤性止水材の耐久性評価
}

\author{
稲 積 真 哉* 川端 秀 雄** \\ 大津宏 康*** 磯 田隆 行 ${ }^{* * * *}$

\section{Evaluation of Durability on Water-Swelling Materials as Seepage Control Works in Waste Landfill Sites}

\author{
by \\ Shinya Inazumi ${ }^{*}$, Hideo Kawabata ${ }^{* *}$, Hiroyasu Ohtsu ${ }^{* * *}$ and Takayuki IsodA ${ }^{* * * *}$
}

\begin{abstract}
This paper estimates the durability of water-swelling materials that is an important element in water cutoff performance of vertical cutoff walls constructed in coastal waste landfill sites. We carry out accelerated deterioration tests on the water-swelling materials. Furthermore, we predict the durability of water-swelling materials based on Arrhenius law.

When Arrhenius law is applied to the result of accelerated deterioration test, the life of water-swelling materials will be estimated about 27 years. This suits the previous results in which decreasing in strength of water-swelling materials will not advance after progress from their curing start for one year. Therefore, it is thought that waterswelling materials are utilizable enough as water cutoff materials of vertical cutoff walls constructed in waste landfill sites for tens of years.
\end{abstract}

Key words : Accelerated deterioration test, Arrhenius law, Durability, Waste landfill, Water-swelling material

\section{1 緒言}

現在，環境意識の高まりにより廃棄物のリサイクルや 再資源化は推進されており, 廃棄物排出量は年々減少傾 向にあるものの，廃棄物処分場の新規建設が困難な事情 も重なり，廃棄物処分場の残余容量は減少の一途を辿っ ている。よって, 廃棄物処分場の残余容量の減少は, 我 が国において解決しなければならない急務の課題である. 従来, 山間谷地部に比較的小規模な内陸廃棄物処分場が 建設されていたが，近隣住民から建設に関して反対の意 見が挙がる，また環境規制が強化されたことから，生態 系や水源を保護するため, 山間谷地部の内陸廃棄物処分 場は建設されなくなっている.1)このような状況下，新規 廃棄物処分場として大規模な海面処分場 (Fig. 1) の建設 が増えている。環境省の調査によると, 平成 21 年度の 最終処分場新規供用開始容量において海面処分場は全体 の約 $26 \%$ を占めており, 海面処分場が重要な役割を果た すようになっている.2

海面処分場もこれまでの廃棄物処分場が抱えていた環 境問題を無視はできず, むしろ海水域に面しているため 廃棄物由来の污染水が漏出しないことを確認しなければ ならない。そこで, 海面処分場における廃棄物埋立護岸 (側面遮水工) として, 埋立処分を行う空間を確保する と同時に污染水の漏出を抑制するために，鋼製遮水壁が 広く用いられている。ここで, 鋼製遮水壁の構造として, 継手箇所に抢ける污染水漏出のリスクが高いという問題
点が挙げられる。そのため，様々な継手がこれまで開発 され，また継手箇所の空隙をモルタルや膨潤性止水材等 で充填することで透水係数の低下が図られている.3)一方, 海面処分場は数十年の長期にわたって供用されるもので あるのに対し, 污染水の漏出は抑えられているが半永久 的な封じ込めが達成されているのか把握できていない現 状にある。よって，海面処分場にて用いられる鋼製遮水 壁においては，供用開始直後のみでなく数十年先まで見 据えた長期的な遮水性能を評価する必要がある.

本研究では, 鋼製遮水壁の遮水性能において重要な要 素である継手充填材（遮水処理材）に着目し, 継手充填 材（遮水処理材）の耐久性を評価する。具体的には，継 手充填材（遮水処理材）として近年幅広く用いられてい る膨潤性止水材に関して, 膨潤膜（膨潤した膨潤性止水 材膜）の劣化促進試験を実施するとともに，得られた結 果打よびアレニウスの法則に基づいた膨潤性止水材の而 久性を予測している。

\section{2 海面処分場, 鋼製遮水壁および膨潤性止水材}

\section{$2 \cdot 1$ 海面処分場}

廃棄物処分場とは，我々が生活する上で排出する廃棄 物を貯蔵し，居住環境を維持するための社会基盤構造物 である。一方，近年の環境意識の高まりから $3 \mathrm{R}$ が促進さ れ，廃棄物の最終処分量は年々減少傾向にある。しかし ながら, 廃棄物処分場（特に内陸廃呆物処分場）の新規建 設は困難であり，結果的に残余容量の逼迫が問題となっ

\footnotetext{
$\dagger$ 原稿受理 平成 25 年 4 月 30 日 Received Apr. 30, 2013 @ 2014 The Society of Materials Science, Japan

* 正会員 明石工業高等専門学校 †674-8501 明石市魚住町西岡, Akashi National College of Tech., Uozumi-cho, Akashi, 674-8501

** 賛助会員 日本化学塗料(株) 干252-1111 綾瀨市上土棚北, Nippon Chemical Paint Co., Ltd., Kamitsuchidana, Ayase, 252-1111

*** 正会員 京都大学大学院 干615-8540 京都市西京区京都大学桂, Kyoto Univ., Nishikyo-ku, Kyoto, 615-8540

$* * * *$ 中国電力(株) テ730-8701 広島市中区小町, The Chugoku Electric Power Co., Inc., Naka-ku, Hiroshima, 730-8701
} 
ている．このような現状において，海面処分場 (Fig. 1) の建設が急ピッチに進められている.2)

廃棄物処分場には，安定型処分場，管理型処分場およ び遮断型処分場の大きく 3 種類に区別できる。これらの 廃棄物処分場の違いは, 廃棄される廃棄物の環境に与え る影響度によって区分される。安定型処分場では，環境 に影響を与えない廃プラスチック等が埋立処分される。 管理型処分場では，有害物質を含んでいる廃棄物ではあ るが自然分解できるレベルの廃棄物が処分される。この 際，地下水や水域に有害物質が漏出しないように，集水 設備ならびに遮水設備等が必要となる。また，遮断型処 分場では，高濃度の有害物質を含んだ廃棄物が処分され るため, 有害物質が漏出されないように完全に外部と遮 断されている，上記の内，海面処分場は主として管理型 処分場に位置している。そのため，海面処分場には有害 物質を含んだ廃棄物が廃棄されるため，海面処分場から 漏水が発生した際には有害物質も同時に漏出し，周辺海 域の環境に多大な影響を与える危険性がある。そこで， 海面処分場では，漏水を防ぐために側面と底面に遮水工 を施すことで遮水・遮へい性能を高める必要がある。

\section{$2 \cdot 2$ 鋼製遮水壁}

廃棄物処分場に扎いて，廃衰物由来污染水の地下水や 水域への流出を防ぐために，側面および底面に遮水工が 施される.4)な打，廃棄物処分場の底面は不透水性地盤も しくは遮水シート工等で遮水性を高める場合が多い. 海 面処分場は立地条件からわかるように，海域に污染水が 漏出しないよう側面遮水工の建設に注意を払わなければ ならない。そこで，海面処分場では側面遮水工として Fig. 2 に示すような鋼製遮水壁が用いられる.5)鋼製遮水 壁とは，鋼製部材を継手によって嵌合しつつ連続的に打

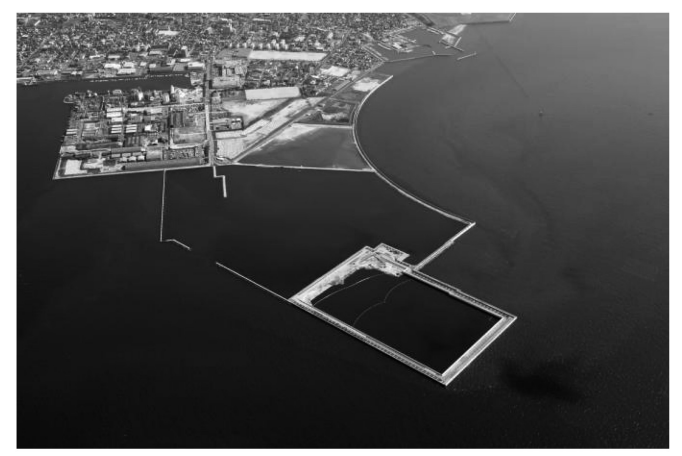

Fig. 1 Panoramic view of coastal waste landfill sites.

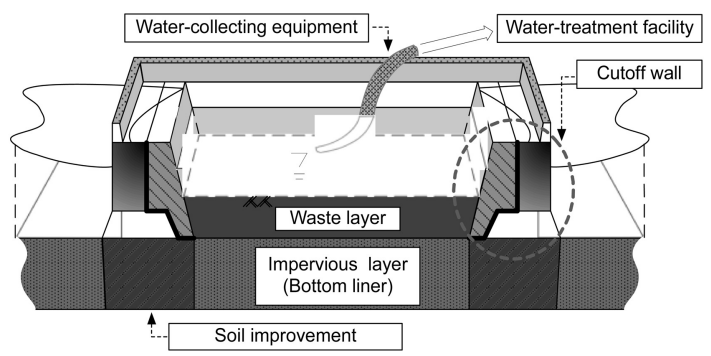

Fig. 2 Outline of seepage control works in coastal waste landfill sites.
設する構造物である (Fig. 3)。鋼製部材自体は，従来か ら構造物の基礎や土留め壁として用いられており，その 遮水性能は非常に高く，不透水として扱える。しかしな がら，鋼製遮水壁は継手部分を有するため，当該継手部 分から水の漏出が考えられる，すなわち，鋼製遮水壁の 遮水性能は，継手部分の遮水性能に大きく影響される。 そのため, 様々な形状の継手部分は, 鋼製遮水壁の遮水 性能向上を目的として考案されてきた.3)同時に，様々な 形状の継手は，低透水性の袋詰めモルタルや膨潤性止水 材を継手内部空間に充填することで内部空間に生じる空 隙を塞いでおり，これらの処理は「継手の遮水処理」と 呼ばれている。

\section{$2 \cdot 3$ 膨潤性止水材}

本研究では鋼製遮水壁の継手部分に用いられる充填材 （遮水処理材）として, 膨潤性止水材に着目している. ここで，膨潤性止水材は熱可塑性エラストマーを母材に, 高吸水性ポリマー，充填材および溶剂を配合した流動性 を有する止水材（シート状もしくは液状）であり，膨潤 膜（膨潤した膨潤性止水材膜）から抽出される水は特定 有害物質について地下水環境基準を満たしている。膨潤 性止水材は, 予め鋼製部材の継手内部に塗布・接着して 用いられる. 膨潤性止水材は自然乾燥させると弾性の固い 膜を形成するが，鋼製遮水壁打設後に水や土中水を取り 込み膨潤し , 結果的に継手内部の間隙を塞ぐ (Fig. 4)。こ れによって, 継手部分は遮水性能の向上が図られる。ま た，膨潤性止水材はモルタル等と比較して十分な柔軟性 を有しているため，鋼製遮水壁の弾性や変形追随性をも

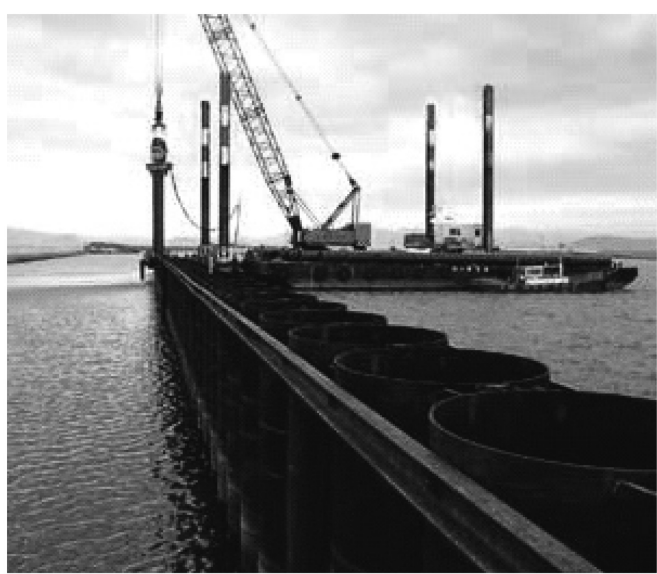

Fig. 3 Seepage control warms by steel pipe sheet piles.

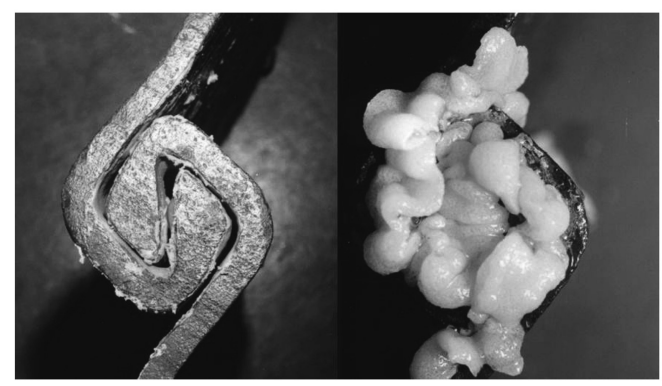

Fig. 4 Before (left) and after (right) swollen state on water-swelling materials. 
向上できる，なお，膨潤性止水材については，様々な条 件下での室内・現場試験が行わ机ており，充填材（遮水 処理材）としての特性・性能が定量的に評価されている. 例えば，水頭差が $40 \mathrm{~m}$ 以下であれば，膨潤性止水材を塗 布した継手は遮水工基準 $\left(k_{e} \leq 1.0 \times 10^{-6} \mathrm{~cm} / \mathrm{s}\right)$ を達成で きる.6.,7)さらに，膨潤性止水材の経時特性についても膨 潤膜強度を指標として言及されている.6),7)なお，膨潤膜 強度とは水により膨潤した膨潤性止水材膜の強度を表し て抢り，これは耐水圧（遮水性能）等に大きく影響を及 ぼす。一例として膨潤性止水材の膨潤膜強度は，浸漬水 温 $20^{\circ} \mathrm{C}$ の水道水において 1 年間で約 $7.2 \mathrm{~N}$ から $0.8 \mathrm{~N}$ まで 低下するものの，1 年経過以降は一定值 $(0.8 \mathrm{~N})$ を保持 することが確認されている.6),7)この要因として，浸漬養 生開始から 1 年以内は膨潤性止水材に含有される高吸水 性ポリマーの溶解が進行傾向にあるものの，1年経過以 降は高吸水性ポリマーの溶解が終了に向かうことが考え られている。なお，高吸水性ポリマーの溶解程度は，膨 潤性止水材が浸漬される水質, 特に水温の影響を大きく 受ける，換言すれば，膨潤性止水材における膨潤膜強度 の経時変化は浸漬水温の調節によって促進させることが でき，これが本研究における膨潤膜劣化促進試験実施の 動機として位置付けられる。なお，本研究において「膨 潤性止水材の劣化」は，「膨潤性止水材の組成分である 高吸水性ポリマーの溶解に伴う膨潤膜強度の低下」と同 義に扱っている。

\section{3 膨潤性止水材の膨潤膜劣化促進試験}

\section{$3 \cdot 1$ 概要}

海面処分場は有害物質を含有し得る廃棄物が廃棄処分 されるため，長期的に有害物質が分解されるまで，もし くは半永久的に有害物質を封じ込めるため，適正に管理 されなければならない。よって，海面処分場の側面遮水 工として用いられる鋼製遮水壁は，長期的・半永久的に 污染水が漏出しないよう, 遮水性能を確保・維持する必 要がある。しかしながら，鋼製遮水壁は供用開始直後に おいて遮水工基準を満たす遮水性能を保持しているもの の，数十年後においても当該遮水性能を保持している保 証，さらに適切な維持補修の計画がない状態で用いられ ている現状にある。よって，本研究では鋼製遮水壁の継
手に充填される膨潤性止水材に着目し，膨潤性止水材の 劣化を考慮した上，長期的な耐久性を評価している。た だし，膨潤性止水材は本来長期間にわたって用いられる ため，オンサイトにおける耐久性・耐用年数の調查は膨 大な時間を要する。そこで，短期間に膨潤性止水材の長 期的な耐久性（長期的な遮水性能）の評価を試みる目的 で，膨潤性止水材を高温水に浸漬させ，膨潤性止水材の 劣化を促進させる膨潤膜劣化促進試験を実施している。

\section{$3 \cdot 2$ 試験方法}

本研究では海面処分場において遮水材として適用され た膨潤性止水材の劣化を考慮するため，膨潤性止水材を 高温水に浸漬させ，且つその条件における膨潤膜の強度 特性を測定する膨潤膜劣化促進試験を実施している。な お，膨潤膜強度を測定する機器には島津製作所製 EZTEST-500N（進入弾性治具： $\phi 3 \mathrm{~mm}$ ）を用いている. 試験方法は以下のと拈りである.

（1） $100 \times 100 \mathrm{~mm}$ の試験片（膨潤性止水材）を準備する.

(2) 下部アクリル板に $\mathrm{t}=2 \mathrm{~mm}$ の膨潤性止水材を貼り 付ける。

（3）上部抢よび下部アクリル板をボルトで留め，劣化促 進試験サンプルとする (Fig. 5).

（4）試験サンプルを水道水（浸漬水温： $20^{\circ} \mathrm{C}, 40^{\circ} \mathrm{C}, 60^{\circ} \mathrm{C}$ 扎よび $80^{\circ} \mathrm{C}$ ) で満たされた水槽にて浸漬させる。

（5）一定期間後，試験サンプルを水槽から取り出し，膨 潤性止水材の中心，中心から $15 \mathrm{~mm}$ 抢よび $30 \mathrm{~mm}$ 離れた位置（測点）の膨潤膜強度を合計 9 点測定す る (Fig. 6).

（6）膨潤膜強度測定後, 試験サンプルを再び水槽に戻し 浸漬させる。

(7)（5)および(6)を繰り返す.

\section{$3 \cdot 3$ 結果と考察}

Fig. 7 は，浸漬水温 $20^{\circ} \mathrm{C}, 40^{\circ} \mathrm{C}, 60^{\circ} \mathrm{C}$ よび $80^{\circ} \mathrm{C}$ の水 道水に浸漬した膨潤性止水材の各測点 (No. 1, 2,3,6,7) に おける膨潤膜強度と浸漬養生日数の関係を示している. ここで，浸漬養生前（膨潤前）における膨潤性止水材の 膜強度は $6.9 \mathrm{~N}$ である。これより，全ての浸漬水温の場合 で，いずれの測点においても浸漬養生日数の経過に伴っ て膨潤膜強度が低下する傾向が認められる。また，中心
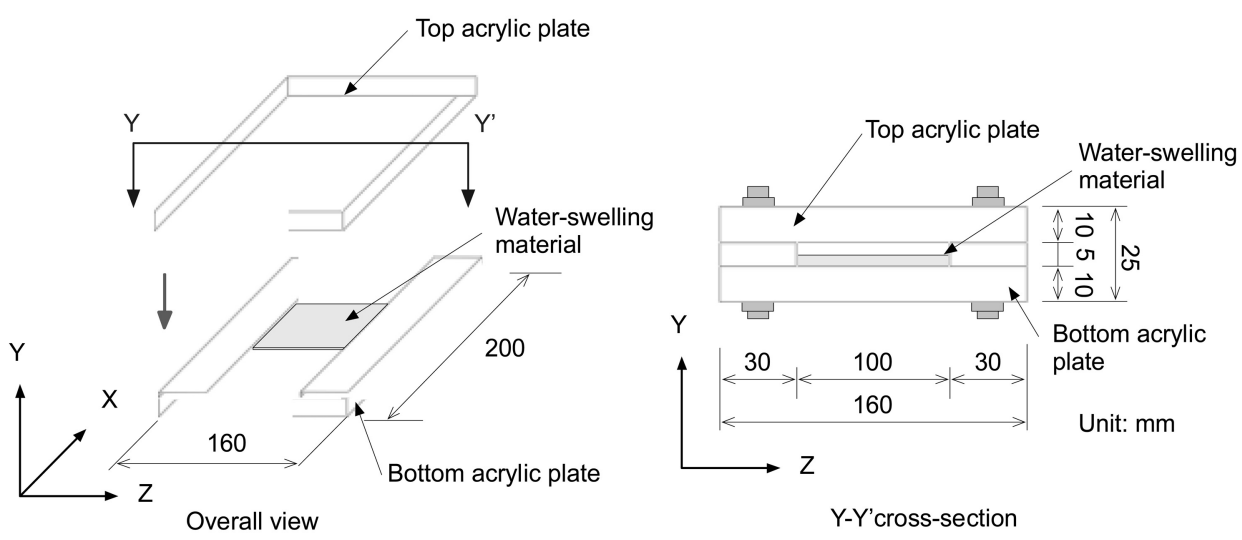

Fig. 5 Outline of specimen on accelerated deterioration tests.

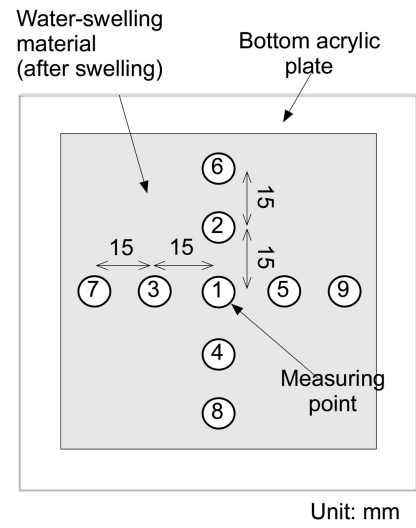

Fig. 6 Measuring points for strength under swollen state. 

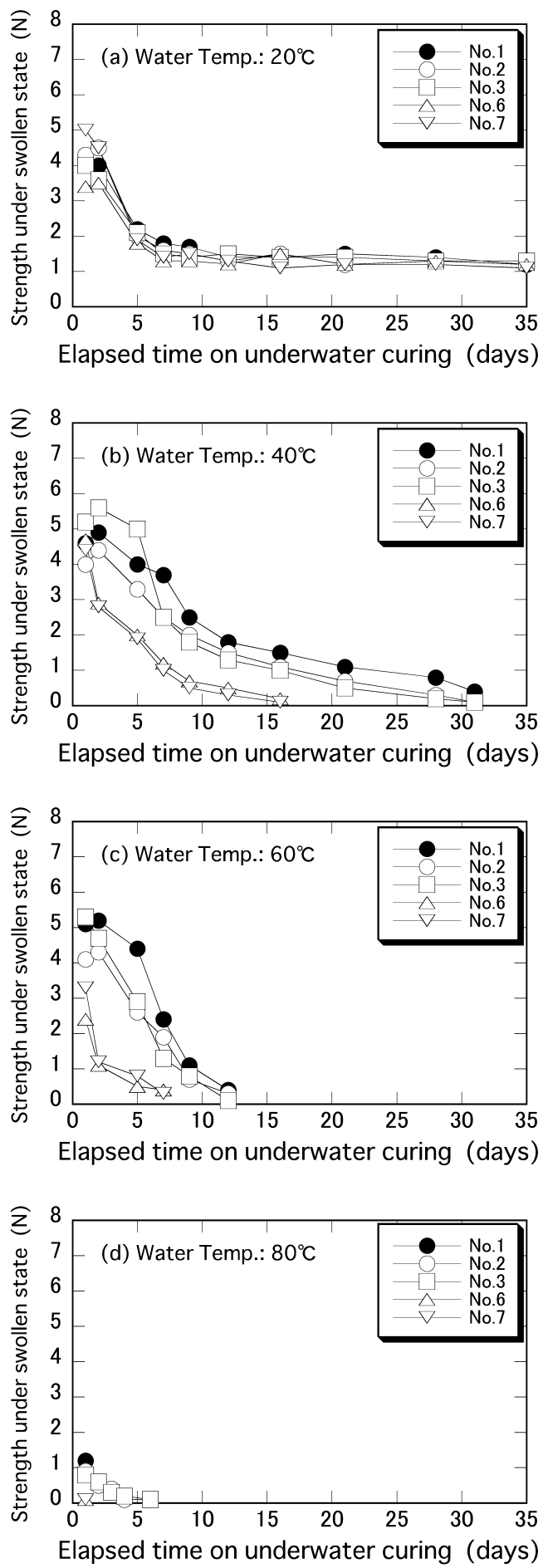

Fig. 7 Relationship between curing and strength under each measuring point and water temperature.

測点から $30 \mathrm{~mm}$ 位置の測点 (No.6, No.7) では，浸漬水温 に応じて他の測点と比べ早期（例えば，浸漬水温 $40^{\circ} \mathrm{C} て ゙$ は 16 日経過後）に膨潤膜強度の測定が不可能であった。 一方，浸漬養生日数の経過とともに，いずれの浸漬水温 において中心測点 (No. 1) の膨潤膜強度が最も大きくな る傾向にある．換言すれば，中心測点 (No.1) に比べて， 中心から $15 \mathrm{~mm}$ 位置の測点 (No. 2, No. 3)，さらに中心 から $30 \mathrm{~mm}$ 位置の測点 (No.6, No. 7) の膨潤膜強度の低 下は浸漬水温の上昇にも応じつつ，より早期に進行する. このように周辺部から中心部へと劣化が進行する原因に

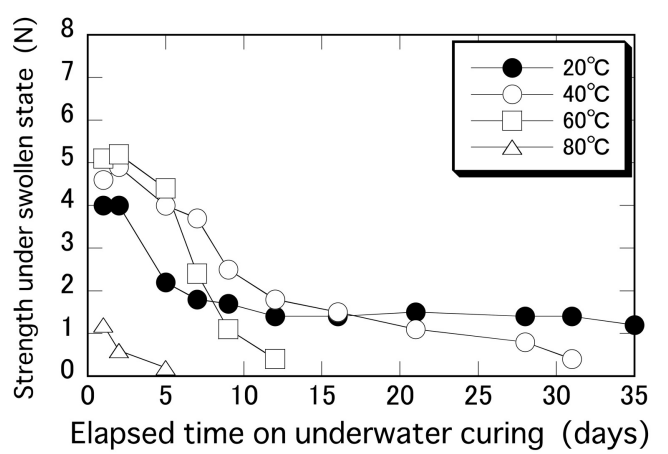

Fig. 8 Relationship between curing and strength under each water temperature (Measuring point: 1).

Table 1 Slope and intercept values in fitted curve.

\begin{tabular}{|l|c|c|c|}
\hline & Minimum & Medium & Maximum \\
\hline Slope $\left(E_{\alpha} / R\right)$ & 6560.7 & 7542.0 & 7746.6 \\
\hline Intercept $(\ln L / A)$ & -22.615 & -16.532 & -7.460 \\
\hline
\end{tabular}

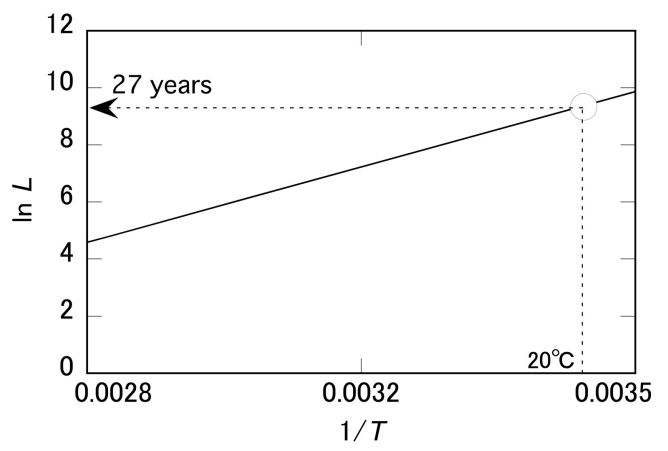

Fig. 9 Relationship between $1 / \mathrm{T}$ and $1 \mathrm{ml}$ at strength under swollen state of $0.8 \mathrm{~N}$.

は，水と膨潤性止水材の接触を挙げることができる。す なわち, 先ず膨潤性止水材の周辺部 (No. 6, No. 7) にお いて水と接触・膨潤が発生するため, 中心部 (No. 1, No. 2, No. 3) の膨潤膜強度は当該周辺部と比較して大き い. 同時に，周辺部 (No.6, No.7) では膨潤性止水材の 組成分である高吸水性ポリマーの溶解も進行する結果, 当該周辺部から膨潤膜強度の低下が進行する。吕,7)ただ し, 膨潤性止水材の周辺部が先に膨潤する結果，中心部 への水の浸入が困難になる.

Fig. 8 は, 浸漬水温 $20^{\circ} \mathrm{C}, 40^{\circ} \mathrm{C}, 60^{\circ} \mathrm{C}$ および $80^{\circ} \mathrm{C}$ の 浸漬条件における膨潤性止水材の中心測点 (No. 1) の膨 潤膜強度と浸漬養生日数の関係を示している。これより, 膨潤性止水材の膨潤膜強度の低下傾向は浸漬水温の上昇 に伴い著しくなる。したがって，膨潤性止水材の劣化は， 浸漬水温の上昇に伴い促進されることが考えられる。な お，この傾向はいずれの測点の膨潤膜強度においても確 認している (Fig. 7).よって, 常温（浸漬水温：20ㄷ）で あれば, 浸漬養生日数の経過とともに膨潤膜強度は $1 \mathrm{~N}$ 程度の一定值で安定しており, 高吸水性ポリマーの溶解 もそれ以上に進行していない（平衡に至っている）と判 断できる。一方, 浸漬水温の上昇に伴い, 膨潤膜強度の 低下は早期に生じており，すなわち，高吸水性ポリマー の溶解が促進されている。 


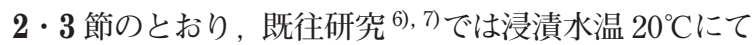
浸漬養生を開始した膨潤性止水材は，1年経過以降，6 年 経過した現時点に打いても膨潤膜強度 $0.8 \mathrm{~N}$ 程度，なら びに透水係数 $1 \times 10^{-9} \mathrm{~cm} / \mathrm{s}$ オーダーを伴う一定の強度 と遮水性能を維持していることが実証されており，膨潤 性止水材の組成分である高吸水性ポリマーの溶解は 1 年 程度で終了に向かうことが明らかになっている．同時に， 既往研究 6), 7)では膨潤性止水材に打ける高吸水性ポリ マーの溶解と, 膨潤膜強度ならびに透水係数との関連性 についても言及している。よって，膨潤性止水材は周辺 部から膨潤することで，中心部に扑て劣化の進行が遅 く，且つ劣化が進行した場合にも周辺部と同様，長期的 には一定の膨潤膜強度ならびに透水係数を保持し続ける ことが予測できる。ただし，膨潤性止水材の劣化におい て浸漬水温の管理は重要である。

\section{4 アレニウスの法則に基づく耐久性予測}

\section{$4 \cdot 1$ 概 要}

膨潤性止水材の耐久性（長期的な遮水性能） - 而用年 数を，オンサイトに扎いて調査することは膨大な時間を 要する。そこで，本研究では膨潤性止水材を水温の異な る水道水に浸漬させることで膨潤膜劣化促進試験を行い， 遮水性能に大きく関与する膨潤膜強度の経時特性を検討 しており，浸漬水温の上昇に伴う膨潤膜強度の経時的低 下傾向が著しいことを明らかにしている。よって，膨潤 性止水材の劣化と浸漬水温には関連性を有しており，高 分子材料等の温度変化に弱い物質の長期耐久性予測にお いて一般的に用いられているアレニウスの法則 ${ }^{8)}$ が成立 すると考えられる。そこで，アレニウスの法則 ${ }^{8)}$ に基づ く膨潤性止水材の耐久性予測を行っている.

\section{$4 \cdot 2$ アレニウスの法則}

アレニウスの法則 ${ }^{8)}$ とは, 劣化によって生じる反応速 度が絶対温度に反比例する Eq. (1)で表される。これは， 材料の温度が高いほど早く変化が進む「反応速度論」に 則っている。

$$
K=A \cdot \exp \left(-\frac{E_{a}}{R T}\right)
$$

ここで, $K$ ：反応速度, $A$ : 定数 (頻度因数),$E_{a}$ ：見か けの活性化エネルギー $(\mathrm{kJ} / \mathrm{mol}), R$ : 気体定数, $T$ : 絶 対温度 $(\mathrm{K})$ である。

また，反応速度と耐用年数の関係は逆数で表すことが できるため, 耐用年数は以下の Eq. (2)で表される.

$$
L=\frac{1}{K}=\frac{1}{A} \cdot \exp \left(\frac{E_{a}}{R T}\right)
$$

ここで， $L ：$ 耐用年数 (year) である.

Eq. (2)の両辺について自然対数をとると, Eq. (3)と なる。

$$
\ln L=\frac{E_{a}}{R} \cdot \frac{1}{T}+\ln \frac{1}{A}
$$

Eq. (3)に打いて $E_{a} / R$ および $1 / A$ は定数となり, $\ln L$ と $1 / T$ に打いて直線関係が得られるため, 温度と耐用年 数との関連が推定できると考えられる.

\section{$4 \cdot 3$ 膨潤性止水材の耐久性予測}

本研究では，材料に固有である頻度因数 $(A)$ や活性化 エネルギー $\left(E_{a}\right)$ に関するデータを取得する試験を実施 しておらず，上記の Eq. (3)から耐用年数を計算できな い。 そこで，後述のとおり膨潤性止水材が想定し得る能 力を発揮できなくなる時点を耐用年数として決定し，浸 漬水温を $40^{\circ} \mathrm{C}, 60^{\circ} \mathrm{C}$ おび $80^{\circ} \mathrm{C}$ にして得られた膨潤膜 劣化促進試験結果から浸漬水温が常温 $\left(20^{\circ} \mathrm{C}\right)$ の際の膨 潤性止水材の耐用年数を予測する。具体的には，浸漬水 温が高温状態の際の試験結果から耐用年数を算出し， $1 / T-\ln L$ 平面にプロットする。 さらに，プロットした点 から Eq. (3)のように自然対数で返した耐用年数と温度 の逆数との関係を表す近似直線を求める。さらに，得ら れた近似直線から浸漬水温 $20^{\circ} \mathrm{C}$ 際の耐用年数を決定す る。本研究では膨潤性止水材の耐用年数を算出する際, 膨潤膜強度が $0.8 \mathrm{~N}$ を下回る時点で当初の遮水性能が維 持できなくなる，すなわち浸漬養生開始から膨潤膜強度 が $0.8 \mathrm{~N}$ となる期間を耐用年数として予測している。こ れは，作用圧 $0.5 \mathrm{MPa}$ の場合，膨潤性止水材の膨潤膜強 度が $0.8 \mathrm{~N}$ 前後でも遮水性能を維持できる既往知見 6$), 7)$ に基づいている。この前提を踏まえ，浸漬水温が $40^{\circ} \mathrm{C}$ ， $60^{\circ} \mathrm{C}$ および $80^{\circ} \mathrm{C}$ で実施した膨潤膜劣化促進試験の結果か ら, 膨潤膜強度 $0.8 \mathrm{~N}$ の際の自然対数で返した耐用年数 と温度の逆数との関係を表した近似直線を作成する.

Table 1 は，膨潤性止水材の膨潤膜劣化促進試験に沶 いて，比較的中心部の測点 $($ No. 1 5) から得られた膨 潤膜強度の経時特性から求めた近似直線の傾き $\left(E_{a} / R\right)$ 打よび切片 $(\ln L / A)$ の最大值，中央值打よび最小值を表 している. 元来，材料に固有である頻度因数 (A) や活性 化エネルギー $\left(E_{a}\right)$ は定数であるため, 耐用年数を計算 する近似直線はほぼ同一であることが望ましい。しかしな がら，本研究に打いて実施した膨潤性止水材の膨潤膜劣 化促進試験では，Table 1 で示すように非常に幅を持った 結果が得られる。この要因として，膨潤性止水材の膨潤 膜劣化促進試験における測定䛊差，ならびに膨潤性止水 材の劣化は必ずしも一様の速度で生じないことが挙げら れる。したがって, 本研究では傾き $\left(E_{a} / R\right)$ および切片 $(\ln 1 / A)$ に関して, Table 1 における中央值を用いて近 似直線を作成している (Fig. 9)。ここで，膨潤性止水材 の耐用年数とは膨潤性止水材が当初の遮水性能を維持で きる期間である．膨潤性止水材は膨潤することで継手内 部の間隙を充填し遮水を行うが, 周辺部の劣化が進行し たとしても中心部が膨潤することで遮水性能を維持する ことが可能である。よって，膨潤性止水材の耐用年数を 予測する際には中心部の劣化傾向に着目すべきであり， 近似直線の作成には周辺部の測点 (No. 6〜9) の結果は 除外している。さらに，得られた近似直線に常温（浸漬

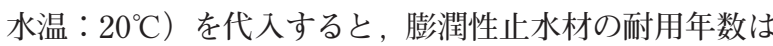
約 27 年と算出・予測される。これは，膨潤性止水材は 浸漬養生開始から 1 年経過以降において劣化がそれ以上 進行しない結果 ${ }^{6)}$, 7) と一致していると考えられる。よっ て，膨潤性止水材は数十年のスパンで用いられる海面処 
分場の遮水工（遮水材）として十分活用できる結果であ る。同時に，膨潤性止水材は高吸水性ポリマー，充填材 および溶剤等の組成比を変化させ, 膨潤膜強度を増大さ

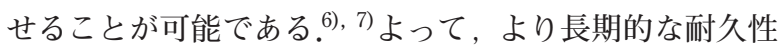
を保持する膨潤性止水材の改変は可能である.

\section{5 結言}

本研究では，海面処分場・鋼製遮水壁の遮水性能にお いて重要な要素である継手充填材（遮水処理材）に着目 し，継手充填材の耐久性を評価した。具体的には継手充 填材として近年幅広く用いられている膨潤性止水材に関 して，各浸漬水温の条件下における膨潤膜劣化促進試験 を実施するとともに，得られた結果およびアレニウスの 法則に基づいた膨潤性止水材の耐久性を予測した.

以下に本研究で得られた知見を示す。

（1）膨潤膜劣化促進試験において，膨潤性止水材の 中心測点に比べて，中心から $15 \mathrm{~mm}$ 位置の測点，さらに 中心から $30 \mathrm{~mm}$ 位置の測点の膨潤膜強度の低下は浸漬水 温の上昇にも応じつつ，より早期に進行する．周辺部か ら中心部へと膨潤膜強度の低下が進行する原因には水と 膨潤性止水材の接触を挙げることができ，先ず膨潤性止 水材の周辺部に打いて水と接触・膨潤が発生するため, 中心部の膨潤膜強度は当該周辺部と比較して大きい.

（2）膨潤膜劣化促進試験において，膨潤性止水材の 膨潤膜強度の低下傾向は，いずれの測点においても浸漬 水温の上昇に伴って著しくなり，膨潤性止水材の劣化は 浸漬水温の上昇に伴い促進される.

（3）膨潤膜劣化促進試験において，浸漬水温が $20^{\circ} \mathrm{C}$ であれば，浸漬養生日数の経過とともに膨潤性止水材の 膨潤膜強度は $1 \mathrm{~N}$ 程度の一定值で安定しており，高吸水 性ポリマーの溶解もそれ以上に進行していない。一方， 浸漬水温の上昇に伴い, 膨潤膜強度の低下は早期に生じ, 高吸水性ポリマーの溶解が促進されている。

（4）膨潤膜劣化促進試験に打いて，膨潤性止水材は 周辺部から膨潤することで中心部において劣化の進行が 遅く，且つ劣化が進行した場合にも周辺部と同様，長期 的には一定の膨潤膜強度を保持し続けることが予測でき る。ただし，膨潤性止水材の劣化に扎いて浸漬水温の管 理は重要である。

（5）膨潤膜劣化促進試験の結果に対してアレニウスの 法則を適用した場合，膨潤性止水材の耐用年数は約 27 年と算出される。これは，浸漬養生開始から 1 年経過以 降において膨潤性止水材の膨潤膜強度の低下が進行しな
い既往の結果と一致している。よって，膨潤性止水材は 数十年のスパンで用いられる海面処分場の遮水工（遮水 材）として十分活用できると考えられる。ただし，耐用 年数以降に関しては膨潤性止水材の維持補修が必要にな ると考えられる。具体的には，シート状の膨潤性止水材 の劣化箇所に液状の膨潤性止水材を再注入する等が考え られるが, 維持補修に関しては今後の課題である。

\section{参 考 文 献}

1) The Landfill System \& Technologies Research Association of Japan, "Landfills in japan (rivised edition)", The Journal of Waste Management (2004)

2) Ministry of the Environment, "http://www.env.go.jp/recycle/waste/kyoninka/h21chosa.pdf" (2013.04.30)

3 ) T. Oki, K. Torizaki, H. Kita, M. Yoshida, Y. Sakaguchi and H. Yoshino, "Evaluation of impermeability performance of the vertical impermeable walls by using steel sheet piles and steel pipe sheet piles”, Proceedings of the 5th Japan National Symposium on Environmental Geotechnology, pp.53-58 (2003).

4 ) Waterfront Vitalization and Environment Research Center, "Design, construction and management manual for managed type waste reclamation”, Waterfront Vitalization and Environment Research Center (2002).

$5)$ M. Kamon and Y. S. Jang, "Solution scenarios of geo-environmental problems", Proceedings of the 11th Asian Regional Conference on Soil Mechanics and Geotechnical Engineering, pp.833-852 (2001).

6 ) S. Inazumi, T. Wakatsuki, M. Kobayashi and M. Kimura, "Material properties of water swelling material used as water cut-off treatment material at waste landfill sites", Journal of Material Cycles and Waste Management, Vol.12, No.1, pp.50-56 (2010).

7 ) S. Inazumi, M. Kimura, T. Kakuda and M. Kobayashi, "Water cut-off performance of $\mathrm{H}$-jointed steel pipe sheet piles with $\mathrm{H}-\mathrm{H}$ joints attaching water-swelling materials", Soils and Foundations, Vol.51, No.6, pp.1019-1035 (2011).

$8)$ M. Ohtsuka, Y. Enya, T. Kobayashi and A. Koizumi, "Segment waterproofing design using hydroxide seal in shield tunneling”, Proceedings of JSCE, No.651, pp.61-79 (2000). 